\title{
RUSSIAN LINGUOCULTURE: THE CONCEPT "JUSTICE" AS A NUCLEAR LINGUISTIC UNIT OF THE CONCEPTUAL FIELD “GUARDIANSHIP”
}

\author{
CULTURA LINGUÍSTICA DA RÚSSIA: O CONCEITO “JUSTIÇA” COMO UMA \\ UNIDADE NUCLEAR LINGUÍSTICA DO CAMPO CONCEITUAL “TUTELA"
}

\author{
CULTURA LINGÜÍSTICA RUSA: EL CONCEPTO DE JUSTICIA COMO UNA \\ UNIDAD NUCLEAR DE IDIOMA EN EL CAMPO CONCEPTUAL DE CÚRATELA
}

\author{
Tatyana I. KOBYAKOVA ${ }^{1}$ \\ Svetlana D. GALIULLINA ${ }^{2}$ \\ Nina L. SUNTSOVA ${ }^{3}$ \\ Rimma Ya. NURIEVA ${ }^{4}$ \\ Gulshat M. OSIPOVA ${ }^{5}$
}

\begin{abstract}
To define the internal content of the concept "justice", that operates in the Russian linguoculture being a nuclear unit of the conceptual field "guardianship", an interdisciplinary method, incorporating historiographical, ideographic, and introspective methods, has been used. In the Russian linguistic world image, the concept "justice" is the basic component of the concept "guardianship". This concept reflects the idea of guardianship as a social protection of the disadvantaged part of the population in the linguistic consciousness of the Russian people. The linguocultural core of the linguistic world image consists of the concepts verbalized in the consciousness of an individual, forming in it the conceptual frameworks with the subject-specific content. From the linguoculturological point of view, the concept "guardianship" as a form of manifesting mercy in the Russian conceptosphere "Spirituality", represents the idea of social and legal protection based on the idea of moral justice. Justice as an absolute virtue coexists in the society in three forms: moral, legal, and political.
\end{abstract}

KEYWORDS: Guardianship. Interdisciplinary research methods. Justice. Russian linguoculture.

RESUMO: Para definir o conteúdo interno do conceito "justiça”, que tem funcionado na cultura linguística da Rússia, como uma unidade nuclear do campo conceitual "tutela", foi empregado um método interdisciplinar, que incorpora os métodos historiográficos, ideográficos e introspetivos. O conceito "justiça" é uma componente básica do conceito

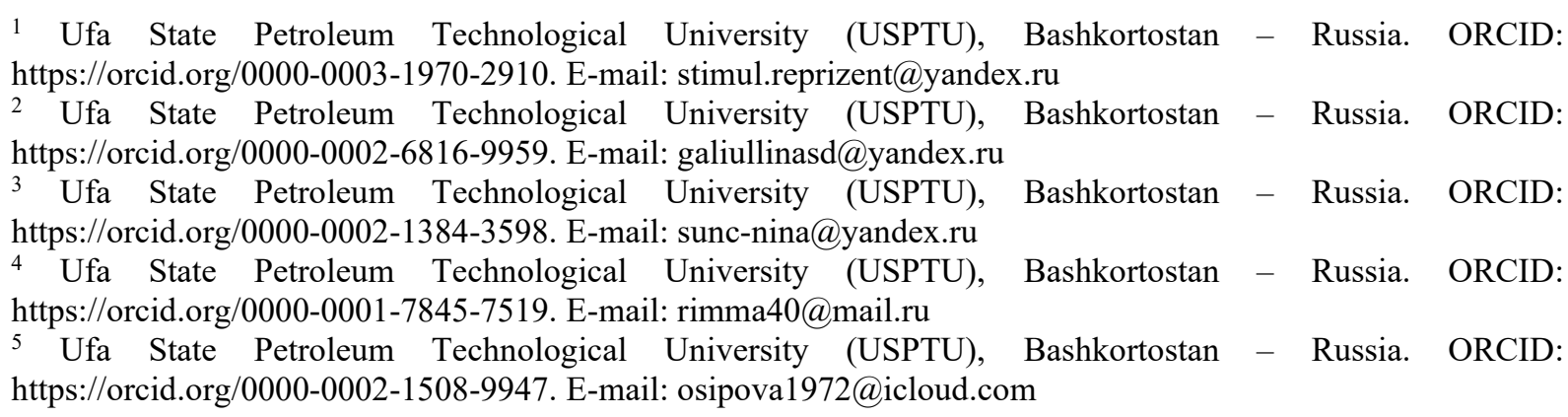


"tutela" na visão linguística russa de mundo. Este conceito realiza uma ideia de tutela como uma proteção social das populações empobrecidas, na consciência linguística dos russos. $O$ núcleo linguístico e cultural da imagem linguística do mundo inclui os conceitos verbalizados na consciência de pessoa, que formam nela campos conceituais com conteúdos temáticos. Do ponto de observação linguístico e culturológico, o conceito "tutela" como uma forma de manifestação de misericórdia no enquadramento conceitual russo "Espiritualidade" é um reflexo da ideia de proteção social e jurídica, baseada na ideia de justiça moral. Três formas de justiça, como uma virtude absoluta, coexistem na sociedade: moral, jurídica e política.

PALAVRAS-CHAVE: Tutela. Métodos de pesquisa interdisciplinares. Justiça. Cultura linguística russa.

RESUMEN: Aquí el contenido interno del concepto de justicia que funciona en la cultura lingüistica rusa y es una unidad nuclear del campo conceptual de cúratela se defina por el método interdisciplinar que incluye tales métodos como historiográfico, ideográfico e introspección. En la imagen lingüistica del mundo rusa la noción de justicia es un componente básico del concepto de cúratela. En la mentalidad de la gente rusa este concepto realiza la idea de la cúratela como la protección social para la parte desdichada de la población. El núcleo cultural lingüístico de la imagen lingüística del mundo consiste de conceptos verbalizados en la percepción del individuo que forman campos conceptuales con relleno temático. En términos de cultorología lingüistica en concepto de cúratela como una manifestación de la espiritualidad en la esfera de conceptos rusa refleja la idea de la protección legal social basada en la idea de la justicia ética. La existencia social de la justicia como una virtud absoluta tiene tres formas, es decir, ética, legal y política.

PALABRAS CLAVE: Tutela. Métodos de investigación interdisciplinarios. Justicia. Linguocultura rusa.

\section{Introduction}

In the conditions of intercultural communications and Russia's entry into the global multicultural educational space, the issue relating to interaction of language, culture and personality remains relevant. The ability of language to model ethnolinguistic and cultural worldview in human consciousness is justified by Wilhelm von Humboldt and his doctrine of the inner form of the word (KAVELIN, 1899) in linguistics, the theory of linguistic relativity of E. Sapir and B. Whorf (SEREBRENNIKOV, 1988) and other scientific researches. The issue of interrelation of linguistic consciousness and national mentality is solved by the efforts of different disciplinary areas of linguistics, researching different forms of cultural expressions in the language and a personality as their concentration (STEPANOV, 1997; UFIMTSEVA, 1996; VEZHBITSKAYA, 1996; VOROBIOV, 1997; WHEELWRIGH, 1997) and other domestic and foreign scientists). The interrelated exploring of language and culture has reflected in the linguoculturological concept of language teaching (SAYAKHOVA, 
2003), which is based on the understanding of language as the data code, forming the foundation for the knowledge about the world, language ability, cultural and historical environment, historical memory, creating a linguistic personality.

The study primarily focuses on determining the internal content of the concept "justice"; it operates in Russian linguoculture being a nuclear unit of the conceptual field "guardianship". The object of the description is the concept "justice" in the structure of the conceptual field "guardianship".

The aim implies the formulation and solution of the objectives relating to linguoculturological and linguo-didactic orientation of the study:

1. To present a summary of the scientific literature on the problem being studied.

2. To substantiate the concept "justice" theoretically, as a nuclear, linguistic unit of the conceptual field "guardianship".

3. To describe the features of the valuable linguistic and creative content of the concept "justice".

The relevance of the study implies the general interest in the development of the historical phenomenon "guardianship" as a social institute of public administration. Political stability and cultural-spiritual development of the country depend directly on planning and implementing for the sound evidence-based social policies and the guardianship is its core. Year after year, for various reasons, the number of the most vulnerable population groups (orphans, disabled people, and children with different incurable or serious diseases, pensioners, migrants and asocial segments) is increasing. All of them need social protection, which is a set of protective measures and means for creating the accessible environment of their activities.

\section{Materials and methods}

The methodological basis of the research relies on the dialectical relationship between the past with the present and the use of the conceptual framework, formed in both historical and social sciences: sociology, philosophy, political science, linguistics. Methodological dominant is the sociocultural phenomenon in the value-semantic area of the language. This underlines the urgency of involving the methods and categories of the indicated sciences, in this regard, the interdisciplinary method, including linguistic and cultural analyses has been used, it combines historiographical and ideographic methods, taken together it allows to 
submit the consistent definition of the significant sociolinguistic and cultural phenomenon; the introspective method, on the basis of which the main method of presenting information reflected in the scientific works of Russian scientists, the principle of free presentation of the material is built.

\section{Results}

1. The linguocultural core of the linguistic world image is composed of the verbalized concepts in the consciousness of the individual generated the conceptual fields with the thematic content in it. In terms of linguodidactics, the conceptosphere is correlated with the linguistic personality thesaurus, its lexicon. Therefore, in order to understand and study the sociocultural space and become its full member, it is necessary to learn how to use the language as a tool for modeling the world image.

2. The concept "guardianship" plays a particular role in the Russian sociolinguistic culture; it holds a special position in the linguistic world image, as it reveals the peculiarities of the social structure in the system of constitutional state.

3. From the linguoculturological point of view, the concept "guardianship" as a manifestation of mercy in the Russian conceptosphere "Spirituality" represents the idea of social and legal protection based, particularly on the idea of moral justice. Linguistic analysis has revealed the transformation of the inner content of the word-concept "justice" in Russian linguoculture.

4. Justice as an absolute virtue, correlated with the idea of universal well-being, coexists in the society in three forms: moral, legal and political. The idea of moral and legal justice is at the core of Russian guardianship as an institution of social relations, serving as a welfare determinant that provides moral and legal, legislative protection of the disadvantaged segments of population. If we consider the fact that justice is based on the idea of universal well-being and equality in the distribution of all benefits, the guardianship, as a form of charity, reflects the same idea from the perspective of the social world order, built on protection and law. 


\section{Discussion}

\section{Problem statement}

The image of the world is an invariant representation of the substantive issues in the consciousness of the person (HUMBOLDT, 1985), focused in the mind in the form of conceptosphere by means of units (stereotypes) determining the lifestyle of the human existence, features of behavior in society. The model of the national image of the world (LOCKE, 2002) (picture of the world) as a product of active spiritual and material life of a person is shown as a space-time diagram of the world order, fixed in the consciousness of the individual at the verbal level and reflecting the peculiarities of the ethnos worldview as a whole and the individual as the representative of the particular culture. The formation of the world image is being implemented through two interrelated operations of thinking: firstly, through the explication, it is the objectification and understanding realities of the real world; secondly, through creation of new image of the world by reflecting the objects of the surrounding reality. It is a peculiar mechanism for correlation of reality, it exists independently of human knowledge and thinking, and the ideal world image is the result of cognitive activity expressed through associatively-verbalized network of semantic relations. According to the principle of linguistic complementarity (BRUTYAN, 2000), the representation of reality is fixed in the consciousness of the man as a part of intellectual world on the basis of the linguistic sign. B. Serebrennikov states that it must be remembered that the formation of the world image in the mind of the individual involved different types of thinking - verbal, practical, imaginative, etc. Sound complex, forming the word, is incapable of reflecting anything. Actually, the result of reflection is the concept, the language is related to reality through the sign correlation, but it does not reflect reality and only displays it in a sign way (SHANSKY, 1975). The linguistic world image does not only describe the structure of being, but also sets the samples of personal and national interpretation of reality. The basic property of the linguistic world image lies in the peculiarities of the strategy formation, stereotypes of thinking, life of society in general and the linguistic personality in particular. The linguistic world image is considered to be a model of the worldview from the perspective of language; it is a verbalized model of the conceptual system of knowledge and ideas about the world. In this case, both the device of the world and the totality of knowledge and ideas about it are described by using language means. The language explains the content of the conceptual world image with the help of certain verbal signs, concepts that form the conceptosphere of the language as a multidimensional and multifaceted structure, and the 
elements reflected in it belong not only to the language, but also to the national culture. The conceptosphere of language is a range of information and cultural facilities; it is a form and mechanism of national and cultural existence in the linguistic consciousness of the individual.

The core of conceptosphere consists of concepts as a result of the arguments for human linguistic and cognitive activity performed in certain historical, cultural and pragmatic conditions (GACHEV, 1998). The didactic side of the concept is manifested in its ability to connect the meaning of reality with the sign in the process of conceptualization and categorization of the world. Studying concepts, a person adopts national and universal culture and forms his vision of the world. The concepts of spiritual values play a specific role in this process as the identifiers of culture; according to the typology of human needs described by Erich Fromm (1997), a sense of deep roots and the desire for assimilation are enclosed in them

In contemporary linguoculturological research, the values, formed in the linguistic consciousness of the individual with the help of linguistic units performing a metaphorical image (it is an abstract representation in the case of spiritual values), are an ideal formation, representing a great importance of objects and phenomena of reality for the society and men, expressed in the form of verbal models (FROLOV, 2001) and determined by the choice of language means and ways of speech activity (ALEFIRENKO, 2010).

One of such spiritual values in Russian culture is the conceptosphere "guardianship".

The history of charity in Russia dates back to the 10th century. But only at the turn of the 17 th and18 th centuries the state organizational form of guardianship and charity saw a gradual expansion and it was finally developed in the 19th century.

It was during the period that a unique model of government care as a form of public service and social institution enshrined in laws and regulations was established in Russia. In the first half of the 19th century the institution of honorary Trustees, overseers and guardians of aristocrats, the merchant class and industrialists was introduced, its aim was to care about the schools and gymnasiums in economic and moral relations, headed by the Governor, whose responsibility included the functions of the trustee and warden; in the second half of the 19th century, Emperor Alexander II and the government developed partnerships with business and the public and became the guarantors of guardianship in various spheres of public life, especially in the field of public education, it meant the historically established national system of educational institutions and their governing bodies, acting in the interests of education of younger generations and responsible for the socialization of children. 
The history of guardianship in Russia is reflected in the scientific writings of the researchers. So, in 1899, the complete works of Russian historian, legal scholar and publicist K. Kavelin were published in the section "Science and universities" (1899), the essence of guardianship was determined in the following way: "The trustee is the authority of the government regarding the University, it manages its own affairs through the institutions and officials" (KOLSHANSKY, 1990).

The history of Russian guardianship is reflected in a number of fundamental writings devoted to the statesmen as guardians of public education. For example, a separate chapter "N. Pirogov is an instigator of the social and pedagogical movement of the 60s (1810-1881), written by Ed. Dneprov in the work, presented by the Research Institute of the USSR Academy of Sciences "Essays on the History of School and Thinking of the Peoples of the USSR. The second half of the 19th century" (Moscow, 1976), is devoted to the personality and activity of the famous guardian of Odessa and Kiev educational districts, the surgeon and the ascetic educator N. Pirogov.

The activity of S. Rumovsky, the first guardian in the Kazan educational district, is described in the book "Stepan Yakovlevich Rumovsky" by G. Pavlova (Moscow, 1979); he was the conductor of educational and scientific ideas and the successful provider of the school district. Scientific works of A. Ivanov ("Higher school of Russia in the late 19th - early 20th centuries" (Moscow, 1991); "Student Corporation of Russia in the late 19th - early 20th centuries: experience of cultural and political self-organization" (Moscow, 2004); "Jewish students in the Russian Empire of the early 20th century: what it was" (Moscow, 2007) and other works), written on the analysis of numerous archival sources, cover the activities of S. Uvarov, A. Razumovsky, A. Golovin. "The formation of the system of University education in Russia" by Petrova (Moscow, 2003) talks about the personalities of Trustees in the educational districts of the Russian Empire - M. Muraviev (first curator of the Moscow educational district); N. Novosiltsev (Trustee of the Saint Petersburg educational district), A. Czartoryski (Trustee of the Vilna educational district), S. Pototsky (Trustee of the University of Kharkov), S. Rumovsky (Trustee of the Kazan school district), F. Klinger (Trustee of the University of Dorpat).

The history of guardianship of public education is set out in a number of fundamental writings devoted to the leading universities of Russia (GUERRIER, 1876). The ideas of Professor Guerrier (1876) sound modern; they are focused on the role of the government in the creation of the harmonious system of guardianship in public education, based on 
legislation. Ikonnikov (1876) considers guardianship as a progressive mechanism in participation of the state and society for university management.

The linguistic interpretation of the concept "guardianship", forming the core of the same conceptosphere, is thoroughly discussed by the authors in the articles "the concept of "custody" in Russian language picture of the world" (GALIULLINA; KOBYAKOVA, 2016), "Ethnolinguistic perception of the world: the concept of "mercy" in Russian linguistic culture" (GALIULLINA; KOBYAKOVA; SUNTSOVA, 2016). Linguistic and cultural analysis of this sociolinguistic phenomenon, and the synergetic approach to its study, has revealed that as a result of the expansion of social practices there is a transformation of meaning of the concept "guardianship", and today it is nothing more than a social institution in the framework of public administration and self-government for the protection of poor and incapacitated persons on the basis of civil and family legislation of the Russian Federation.

One of the main problems of the modern approaches to the study of guardianship, including charitable activities, is poorly developed terminological apparatus and, consequently, discrepancies in the understanding of guardianship as a sociocultural phenomenon, linguo and conceptual space and language units, forming its core, have been poorly explored.

One of the basic concepts of guardianship is the sociocultural concept "justice"; the study of it is devoted to the work of both domestic and foreign scientists.

The following items attract particular attention in the framework of the study:

1) Leontjeva and G. Muntyan (2009) in the article "Justice as a social concept" suggest to use the phrase "social concept" in relation to "justice", since this cultural phenomenon has a wide substantive (denotative) field, which allows to actualize its ontological component;

2) Kryakhtunova (2018) in the thesis "The shift lingoucultural concept "justice" (on the material of Russian linguoculture)" considers the concept "justice" as the shift linguocultural phenomenon, representing a mental formation, its structure consists of two polar evaluation areas, positive and negative, they are equal axiologically and characterized by situational reversion;

3) Skromnaya and Vorobyova (2019) in the psychological research "the concept "justice" in Russian linguoculture" analyze the concept "justice" with regard to the genotype of Russian culture;

4) Yakusheva (2008) in the article "Conceptualization of "justice" in the orthodox culture" comes to the conclusion that in Russian orthodox culture the concept of "justice" 
forms a peculiar semantic lacuna, which is filled situationally, in assessing the circumstances. Neither customs, nor religious commandments or the laws cannot claim the role of the benchmark, the initiating action is a reference.

The scientific novelty of the research lies in the synergetic approach to the linguoculturological description for the internal content of the sociocultural concept "justice" as a nuclear unit of the conceptual field "guardianship".

The theoretical significance consists in the development of linguocultural conceptology relating to the study of concepts as sociocultural values.

\section{The concept "justice" as a nuclear unit of the conceptosphere "guardianship}

Guardianship as one of the forms of charity originated in the times of Russian princes Vladimir Sacred and Yaroslav the Wise: the bratchina and fraternal alliances appeared. These public organizations provided care services and acted on the basis of self-government, created educational organizations, printing houses, translated textbooks and took care of the opening schools for children in the spirit of Orthodoxy. In the era of Peter the Great's reforms, the state organizational form of guardianship began gradually to take shape, and by the middle of the 19th century, Russia established a unique model of government custody as a social institution, the purpose was the reasonable provision of the needy and poverty alleviation. This model existed until the October revolution of 1917 (GUERRIER, 1876).

Guardianship as a form of charity is an integral part of the Russian linguistic world image, in particular, the major component of the conceptosphere "Spirituality". For the Russian people the concept "spirituality" is especially significant. As a system of moral values it is initially revealed in the texts of the Scriptures, the Traditions of the Holy Fathers. Thus, the Bible highlights the basic universal human values, such concepts as love, truth, evil, beauty, peace, wine, sin and so on. In the sources of ancient Russian literature, for example, in "the Teaching of Vladimir Monomakh", such concepts of spirituality as beauty, peace, harmony of universe, love, compassion (mercy), and mind are identified.

Philosophers and scientists of the 19th and 20 th centuries consider spirituality as the basis of the objective world and the most important, or the dominant cultural values, forming the national mentality of the linguistic identity. Among the major dominants of Russian spirituality, they primarily allocate humanity (charity), which is manifested in love and tolerance for one's neighbor, and justice and 23 others. 
In the framework of the study, the concept "justice" deserves particular attention being a nuclear component of the linguistic and cultural phenomenon of "guardianship" in the Russian linguistic world image, which is regarded as a social institution of human interaction for the purpose of legal protection or charitable assistance. Justice is one of the main spiritual values of the Russian national mentality and the basic property, the system of guardianship in the Russian society is built on it.

Vladimir Dahl (1978-1980) associates the semantics of words with truth, justice, right, with what is done by the truth, in all. However, the word "justice" is not fixed in the dictionary. In the Brockhaus and Efon Encyclopedic Dictionary "justice" is interpreted as an element of legal awareness, the highest principle of mutual, above all legal, relations between people, the idea of which, according to $\mathrm{H}$. Spencer, is the recognition of individual human rights to have free activity and use the benefits that it brings.

Spencer (1929) points to the duality of justice, it is the idea of equality and inequality in the distribution of cultural and material values created in society. The idea of justice in this case is related to the concept of equality (equity), but by no means identical to it. According to the modern Russian dictionaries of synonyms, token "equality" is identical to such words as equality, equally, and comes from ancient Russian rav'n', rav'nyj, the meanings are flat, smooth, and similar. In Russian language the word appeared in the 11th century, it descended from the original Russian forms of "flat" (cf. Polish - rowny (flat, equal), Slovak - rovny (flat, equal). The form with the initial "ra" is old Slavonic in its origin (SHMELEV, 2002; SREZNEVSKY, 2017). Equality provides a similar, but not identical social position (cf. similar is to bear a resemblance to anyone, anything; the same is exactly alike.

The connection between concepts "right" and "law" is highlighted in the vocabulary entry in the Encyclopedic Dictionary of the Granat Russian Bibliographical Institute. It is mentioned: "the right is both the regulation of mutual individual relations, united in society, and that individuals are granted or provided by this regulation; and finally, that this regulation is considered to be the most correct or appropriate justice" (FUTURA, 2017). In this case, the concept "justice" can be defined as the correspondence between the activity of people and their social position, between their rights and duties, including the distribution of benefits in accordance with the ideas of justice or injustice.

In the modern Russian dictionaries (OZHEGOV; SHVEDOVA, 1996) "justice” is 1) a thing confirms with something equitable, performed in accordance with the truth, actions, 2) something impartial (without prejudice), honest attitude to someone / something, 3) conformity of human relations, laws, orders established by the society norms, requirements. 
Justice is associated as a form of altruism, a willingness to act selflessly for the benefit of others, particularly for protection and assistance of individuals. And this is moral (ethical) justice, involving "proportionality in the distribution of benefits and burdens of people living together" (VINOGRADOV, 2007, p. 537).

Moral justice regulates relations in community, as it implies, first of all, the equality among all members of society to be happy and to have the necessary benefits. The predominance of the moral aspect is also indicated by the etymology of the word. Russian "justice" goes back to the common Slavonic noun "pravda" (cf.: Poland. sprawiedliwy means “fair”) (SOLOVYOV, 1998; VEZHBITSKAYA, 1996; VORKACHEV, 2004).

According to the materials of the dictionary by A. Gruzberg, the sources of the 16th and 17 th centuries it was in the diplomatic correspondence of Moscow and the united PolishLithuanian state, although, compared with the word "truth", it is still used significantly less frequently (259 cases to 10). Later in business and scientific texts the word "justice" is used in the meaning of "truth", "accuracy". Then the meaning "tribute" is added. The word is formed from the adjective "s-pra-ved-liviy"; it consists of two roots, -pra- (true, right) and -ved- (to know).

It is no accident that the word "justice" is used in Russian as a synonym for "right" and "true". This linguistic fact is also indicated in the Church Slavonic dictionary of Russian language (St. Petersburg, 1900).

N. Berdyaev points out that the search for truth (absolute truth) has always been a phenomenon specific to the Russian man (BERDYAEV, 2001). Truth is a reality, recreating a coherent world image; a man is searching for "justice and validity" there. The truth as a property of human cognition is an ideal of righteousness and sophistication, it is a transfer of submissions about ideal social relations in the summarized form (ARUTUNOVA, 1991; VOROBIOV, 1997) and, consequently, about moral justice, which is comparable to the notion "conscience", it is the responsibility for their behavior to surrounding people, society (cf.: with a clear conscience, remorse, in all conscience, and other idioms). It is the "conscience" that obliges a person to give himself to the service of certain spiritual values (kindness, mercy, justice, etc.). In this case, justice is expressed in a person's demand for evaluation both their own and others people's actions according to the existing concept of the distribution of benefits and penalties in society (cf.: to act fairly, to seek, to establish justice, to reach justice, etc.).

The second, legal aspect of justice is due to the influence of Western European culture. Etymologically, the Latin "justitia" is the basis of the Western European concept "justice"; it 
goes back to jus (law). From a legal point of view, justice is a set of normative rules governing social relations, including civil relations. This form of justice is primarily associated with the law as a system for the protection of human rights, directed at cooperating of their activities and the elimination of social and legal conflicts in society; legal justice is based on the idea of pure reason (WHEELWRIGHT, 1990), that is, a priori knowledge.

From here, there are two interrelated forms of legal justice in society (identified by Aristotle in the ancient world): firstly, it is distributive justice (equal share, everyone gets what he deserves, to each according to his needs); secondly, it is egalitarian justice (distribution of benefits and punishment, regardless of their social, property and other status in society). M. Klimenko (LEONTIEV, 2004) emphasizes that humanity's appeal to the problem of justice, as a rule, has been associated with the periods of deterioration of the social situation, when it is necessary to find a way out of the intense living conditions. The idea of guardianship as a social institution becomes the way out; its work is designed to implement the legal protection and charitable assistance to the poorest sections of the population.

The correlation of moral sanctions with the legal aspect of justice is clearly presented in modern definitions used in different scientific spheres

In the dictionary of terms of general and social pedagogy (Ekaterinburg, 2006), "justice" is correlated with the idea of creating equal social opportunities for all members of society to realize their abilities and meet the vital needs (ACADEMIC, 2017).

In philosophy, the concept "justice" is defined as a common moral sanction of joint human interaction, it determines the way of justification and the distribution of desires, interests, duties between them; this is "a moral principle, which means punishment for evil and reward for good" (SHORT PHILOSOPHICAL DICTIONARY).

In jurisprudence, it is a universal principle of intergovernmental and social relations, serving as a moral guide in the law-making, law-enforcement types of human activity (GREAT LEGAL DICTIONARY0. In economic terms, "justice" is the basic concept of the welfare economy, where it is understood as the impartiality or disinterest (fairness). This understanding of justice was named in honor of its author, John Rawls (1971). In his book The Theory of Justice, he argues that justice is a sign of a social order that individuals would choose if they were not influenced by purely personal interests. In this disinterested state, they seem to conclude an agreement regarding the nature of the society and its economic structure. "Ignorance" of their interests does not allow them to know the position (determined by abilities, gender, race) that they will occupy in this society. In this case, a society with four properties will be chosen and these properties can be considered as the properties of justice. 
Political science defines justice as the implementation of natural or normalized relations between political parties, social institutions and citizens, the state apparatus and population [http://enc-dic.com/polytology/Spravedlivost-politicheskaja-1226.html]. And in this case, it is possible to identify the third aspect of justice, political, depending on factors such as the form of political organization, the maturity of the political culture, and hence the political regime, the distribution of public and political interests.

It is indicated from the given definitions, used in different spheres of social life, that in modern Russian linguoculture, the inner content of the concept "justice" is a set of three aspects - moral and social (ethical), regulatory and socio-political, it allows us to distinguish the following basic semes in its internal structure:

1) morality as norms and rules of human behavior, based primarily on such moral qualities as conscience and truth;

2) the right, as an opportunity to distribute public goods and punishments on the recognition of the moral value of people provided by the laws of the state regardless of the situation and specific characteristics;

3) political color, i.e. related to the implementation of policy and based on state and legal relations;

4) the law as a binding and irrevocable rule in the system of social and legal relations;

5) impartiality as a characteristic of decisions and actions taken and carried out exclusively on the basis of principles, regardless of preferences and interests that are satisfied or violated.

Thus, the concept "justice" has a complex internal structure, which reflects the idea of applying the same measure (according to conscience and the law) to all people, despite their social belonging. "Supreme justice is for everybody", it reflects the essence of Russian justice and only borders on the concept of legitimate justice, which is the result of the formation of state and legal institutions. Justice is a moral and value phenomenon of social life and legitimacy is political and legal (ЯКУШЕВА,2008).

\section{Conclusion}

The study describes the main language universals implementing the concept "justice" in the Russian linguistic world image, it is the basic component of the concept of "guardianship" and a moral and legal regulator of social and legal relations. This concept 
implements the idea of guardianship as a social protection of the disadvantaged part of the population in the linguistic consciousness of the Russian man.

As the result of the study, the authors comes to the conclusion that the linguocultural core of the linguistic world image consists of verbalized concepts in the mind of the individual, forming conceptual fields with thematic content in it. The concept "guardianship" is an important part of Russian linguoculture, it occupies a special place in the linguistic world image, as it reveals the peculiarities of the social structure in the system of the state. From the linguoculturological point of view, the concept "guardianship" as a form of mercy manifestation in the Russian conceptual sphere "spirituality" reflects the idea of social and legal protection based, first of all, on the idea of moral justice. Linguistic analysis has revealed the transformation of the inner content of the concept "justice" in Russian linguoculture.

Justice is an absolute virtue, correlated with the idea of universal well-being; it coexists in society in three forms - moral, legal and political.

\section{REFERENCES}

ALEFIRENKO, N. Lingvokulturologiya: tsennostno-smyslovoye prostranstvo yazyka (Linguoculturology: value and meaning space of language. Study guide). Moscow: Flinta: Nauka, 2010. p. 288.

ARUTUNOVA, N. Istina: fon i konnotatsii. Logichesky analiz yazyka. Kulturnye kontsepty (Truth: background and connotations. Logical analysis of language. Cultural concepts). Moskow: Nauka Publ, 1991. p. 21-30.

BERDYAEV, N. Russkaja ideja. Osnovnye problemy russkoj mysli XIX i nachala XX veka (Russian idea. The main problems of Russian thought of the nineteenth century and early twentieth century). Moscow: EKSMO-Press; Kharkov: Folio, 2001. p. 11-249.

BRUTYAN, G. Jazyk i kartina mira. Jazyk i kultura (Language and world picture. Language and culture). Ufa: BSU, 2000. p. 55-59.

\section{BYKOV, A. Social'naja zashhita detej v Sibiri v XIX - nachale XX veka (Social} protection of children in Siberia in the 19th - early 20th century). Aktual'nye problemy teorii i praktiki sotsial'noy raboty s sem'yami i det'mi (Actual problems of the theory and practice of social work with families and children). Tomsk, 2010. p. 143-149.

FASMER, M. Etimologicheskii slovar' russkogo yazyka. (Etymological dictionary of the Russian language). (O.Trubacheva, Trans.). Moscow: Astrel: AST, 2003.

FROLOV, I. Filosofskii slovar' (Philosophical Dictionary). 7. ed. Moscow: Respublika Publ., 2001. p. 536-537. 
GACHEV, G. Nacional'nye obrazy mira. Kurs lekcij (National images of world: Course of lectures). - M.: Publishing center "Academy", 1998. 432 p.

GALIULLINA, S. Problema popechitel'stva o narodnom obrazovanii v dorevoljucionnoj istoriografii (The problem of guardianship of public education in pre-revolutionary historiography). Vestnik of Tomsk State University. History, v. 3, p. 81-83, 2012.

GUERRIER, V. Po povodu stat'i v «Russkom vestnike»: k universitetskomu voprosu (About the article in the "Russian Vestnik": to the University question). Vestnik Evropy, v. 10, p. 768-798, 1876.

HUMBOLDT, W. Jazyk i filosofija kultury (Language and philosophy of culture). Moscow: Progress, 1985.

IKONNIKOV, V. Russkie universitety v svjazi s hodom obshhestvennogo obrazovanija (Russian universities in connection with the course of public education). Vestnik Evropy, v. 4, p. 161-206, 1876.

KAVELIN, K. Sobranie sochinenij. Nauka filosofija i literature (Collected works. Science, philosophy and literature). Vol. III. Saint Petersburg: Printing House of M. Stasyulevich, 1899. p. 228-229.

KLIMENKO, T. Spravedlivost' kak princip prava (Justice as a principle of law). Science Vector of Togliatti State University, v. 1, n. 4, p. 135-137, 2011.

KOLSHANSKY, G. Ob'ektivnaja kartina mira v poznanii i jazyke (Objective picture of the world in knowledge and language). Moscow: Nauka, 1990.

LEONTIEV, A. Jazykovoe soznanie i obraz mira (Language consciousness and image of the world). Language and speech activity in general and pedagogical psychology: selected psychological works. Moscow: Publishing house of psychological and social institute, 2004. p. 123-140.

LOCKE, J. Essays on the Law of Nature. In: Goldie, M. (Ed.). Locke J. Political Essays. Cambridge: Cambridge University Press, 2002. p. 79-134.

OZHEGOV, S.; SHVEDOVA, N. Tolkovyi slovar' Russkogo yazyka: 80000 slov i frazeologicheskikh vyrazhenii (Explanatory dictionary of Russian language: 80,000 words and phraseological expressions). Moscow: Az, 1996.

SAPIR E. Izbrannye trudy po jazykoznaniju i kul'turologii (Selected works on linguistic and cultural studies). Moscow: Progress publishing house, 1993.

SAYAKHOVA, L. Lingvokulturologicheskaja koncepcija obucheniju russkomu jazyku. Russkoe slovo v mirovoj culture. Saint Petersburg, 2003. p. 408-412.

SEREBRENNIKOV, B. Kak proishodit otrazhenie kartiny mira v jazyke (As there is a reflection of a picture of the world in language). Moscow, 1988. p. 6, 81-83. 
SHANSKY, N. Kratkij jetimologicheskij slovar russkogo jazyka: posobie dlja uchitelja (Short Etymological Dictionary of Russian: Guide for Teachers). 3. ed. Moscow, 1975.

SHMELEV, A. Jazykovaja kartina mira. Materialy k slovarju (Language picture of the world. Materials for the dictionary). Moscow: Languages of Slavic culture, 2002.

SOLOVYOV, V. Duhovnye osnovy zhizni. Izbrannye proizvedenija (The spiritual bases of life. Selected works). Rostov-on-Don, 1998. p. 122-276.

\section{SREZNEVSKY, I. Materialy dlja slovarja drevnerusskogo jazyka po pismennym} pamjatnikam (Materials for the Dictionary of the Old Russian Language According to Written Monuments) Available: https://commons.wikimedia.org/wiki/File:Срезневский. Access: 22 Nov. 2017.

STEPANOV, Y. Slovar' russkoy kul'tury: Opyt issledovaniya (Constants. Dictionary of Russian culture: The experience of the study). Moscow: Languages of Russian culture, 1997.

THORIK, V. Lingvokulturologija i mezhkulturnaja kommunikacija (Cultural linguistics and intercultural communication. Study guide). V. Thorik, N. Fanyan. (2nd ed). Moscow: GIS, 2006.

UFIMTSEVA, N. Russkie: opyt eshhjo odnogo samopoznanija (Russians: the experience of another self-cognition) Ethno-cultural specificity of linguistic consciousness. Moscow, 1996. p. $139-163$.

VEZHBITSKAYA, A. Yazyk. Kul'tura. Poznanie (Language. Culture. Cognition). Moscow: Russion Dictionaries, 1996.

VINOGRADOV, S. K. Lingvisticheskomu ponimaniyu tsennosti (Towards a linguistic understanding of value). In Russkaya slovesnost' v kontekste mirovoi kul'tury (Russian literature in the context of world culture). N. Novgorod, 2007. p. 93-97.

VORKACHEV, S. Schast'e kak lingvokulturnyj koncept (Happiness as a Linguocultural Concept). Moscow: Gnozis Publ., 2004.

VOROBIOV, V. Lingvokulturologiya: teoriya i metody (Linguo-culturology: theory and methods). Moscow: PFUR Publ., 1997.

WHEELWRIGHT, P. Metafora i realnost' (Metaphor and reality). Theory of metaphor. Moscow: Progress, 1990. p. 82-109.

GALIULLINA, S. D.; KOBYAKOVA, T. I.; SUNTSOVA N. L. Ethnolinguistic perception of the world: the concept of "mercy" in Russian linguistic culture. Modern research of social problems, v. 28 , n. 4-2, 2016. DOI: 10.12731/2077-1770-2016-4-2-186-203

GALIULLINA, S. D.; KOBYAKOVA, T. I. The concept of "custody" in Russian language picture of the world. Filologické vědomosti, n. 1, 2016. Available:

http://sociosphera.com/en/scientific_journals/filologicke_vedomosti/filologicke_vedomosti-12016/. Acsess: 06 Feb. 2021. 
LEONTJEVA, E.; MUNTYAN, G. Justice as a social concept. 2017. Available:

https://cyberleninka.ru/article/n/spravedlivost-kak-sotsialnyy-kontsept. Access: 21 Nov. 2017.

KRYAKHTUNOVA, M.M. The shift lingoucultural concept "justice" (on the material of Russian linguoculture). Available: http://cheloveknauka.com/. Access: 21 Nov.2017.

SKROMNAYA, I. I.; VOROBYOVA, V. I. The concept "justice" in Russian linguoculture. Available: http://ejournal.pnu.edu.ru/media/ejournal/articles. Access: 22 Nov 2017.

YAKUSHEVA, T. I. Conceptualization of "justice" in the orthodox culture. Available: http://www.unn.ru/pages/issues/vestnik_soc. Access: 22 Nov 2017.

DAHL, V. The explanatory dictionary of the living great russian language. Moscow, 19781980. v. 3, p. 377.

SPENCER, H. Sociological theory. Available: https://slovar.cc/enc/brokhauz-efron2. Access: 22 Nov 2017.

ACADEMIC. Available: https://social_pedagogy.academic.ru. Access: 22 Nov 2017.

SHORT PHILOSOPHICAL DICTIONARY. Available:

http://platona.net/board/filosofskij_slovar/spravedlivost. Access: 22 Nov 2017.

GREAT LEGAL DICTIONARY. Available: https://dic.academic.ru. 22 Nov. 2017.

\section{How to reference this article}

KOBYAKOVA, T. I.; GALIULliNA, S. D.; SUNTSOVA, N. L.; NURIEVA, R. Y.; OSIPOVA, G. M. Russian linguoculture: the concept "justice" as a neuclear linguistic unit of the conceptual field "guardianship". Rev. EntreLínguas, Araraquara, v. 7, n. esp. 2, e021012, 2021. e-ISSN: 2447-3529. DOI: https://doi.org/10.29051/el.v7iesp.2.15138

Submitted: 05/01/2021

Required revisions: 26/02/2021

Approved: 24/03/2021

Published: 01/06/2021 